\title{
脳卒中片麻痺患者における下肢駆動型車椅子の有用性
}

牧野健一郎* 吉本 奈 美* 和 田 太* 蜂須賀研二*

\section{Usefulness of a Leg-pedaled Wheelchair for Hemiplegic Patients}

\author{
Kenichiro Makino, ${ }^{*}$ Nami Yoshimoto, ${ }^{*}$ Hutoshi Wada, ${ }^{*}$ Kenji Hachisuka*
}

\begin{abstract}
Background : Although hemiplegic patients often use an ordinary wheelchair $(\mathrm{OW})$, by propelling the hand rim with the unaffected hand and pushing the ground backward using the unaffected leg, it is a hard task for them over any great distance. If patients could drive a leg-pedaled wheelchair (LW) using both legs, it would be less hard on them. Aims: This study was performed to determine whether or not hemiplegic patients can pedal the $\mathrm{LW}$, and whether pedaling the $\mathrm{LW}$ is easier and faster than using an ordinary wheelchair. Methods: The subjects were 5 poststroke hemiplegic patients whose severity of lower extremity paralysis was III or IV on Brunnstrom's Motor Recovery Stage. The subjects practiced propelling a standard wheelchair for the OW trials and pedaling an EZchair ${ }^{\circledR}$ for the LW trials. After the subjects became skilled in driving both wheelchairs, they were asked to propel the OW and to pedal the LW on a slalom course to evaluate controllability, and on a rectangular course to evaluate wheelchair speed. Physiological cost index (PCI) was obtained for evaluation of driving efficiency. Results: All subjects could pedal the LW without any trouble. The wheelchair speed of the LW on both courses was faster than the OW. The PCI when pedaling the LW on the rectangular course was lower than when propelling the OW. However, the LW was less controllable in braking. Conclusion: Although the LW used still requires some minor modifications, we believe that a LW is suitable for hemiplegic patients who want to travel a long distance in their wheelchairs. (Jpn J Rehabil Med 2003; 40 : 617-620)
\end{abstract}

要 旨：脳卒中片麻痺患者は，非麻痺側の上下肢を用いて車椅子を駆動することが多いが， 効率が悪く長距離の移動には向かない. 下肢は上肢よりも強い力を発揮することができ，重度 片麻痺患者でもリカンベント型エルゴメーターを漕げることが多い。そこで，これらの患者に 対して下肢駆動型車椅子の有用性を検討する目的で予備的実験を行った。対象は脳卒中片麻痺 患者 5 名で, 十分な駆動訓練に続いて, 下肢駆動型車椅子と普通型車椅子の両方で外周コース とスラロームコースを駆動した際の駆動速度と Physiological Cost Index（PCI）を算出した. 駆動速度はいずれのコースでも下肢駆動型車椅子が速く，PCI は外周コースで下肢駆動型車椅 子が有意に低值であった。一方，減速ブレーキがない，ペダルが移乗の邪魔になるなどの問題 点も指摘された。下肢駆動型車椅子は改良が必要であるが，片麻痺患者にとって有用な移動手 段となりうると判断した。(リハ医学 $2003 ； 40: 617-620$ )

Key words : 脳卒中 (stroke), 片麻痺（hemiplegia），車椅子（wheelchair）,下肢駆動 (leg-pedaling)

\section{はじめに}

脳卒中片麻痺患者が車椅子を操作する場合，非麻痺 側の上肢で片側のハンドリムを回し，非麻痺側の下肢
で床面を蹴りながら車椅子の推進と操舵を行うことが 多い. しかし，この方法では車椅子の駆動速度は遅 く，長距離の移動や斜面での駆動・後退が困難であ る1)。また，駆動速度を高めようと努力すればするほ

2003 年 4 月 23 日受付, 2003 年 8 月 19 日受理

* 産業医科大学りハビリテーション医学講座/テ 807-8555 福岡県北九州市八幡西区医生ヶ丘 1-1

Department of Rehabilitation Medicine, University of Occupational and Environmental Health 
表 1 被験者

\begin{tabular}{ccccccc}
\hline 被験者 & 年齢 & 性別 & 病型 & 麻痷側 & $\begin{array}{c}\text { 発症後 } \\
\text { 経過 }\end{array}$ & $\begin{array}{c}\text { 下肢 } \\
\text { ステージ }\end{array}$ \\
\hline 1 & 55 & 女 & 脳出血 & 右 & 3 カ月 & III \\
2 & 62 & 男 & 脳梗塞 & 左 & 19 力月 & III \\
3 & 48 & 男 & 脳出血 & 左 & 3 力月 & III \\
4 & 70 & 男 & 脳梗塞 & 右 & 2 力月 & III \\
5 & 65 & 女 & 脳出血 & 右 & 2 力月 & IV \\
\hline
\end{tabular}

ど体幹の前後方向の動摇が増し, 体幹はより不安定と なる。一方, 重度の片麻脾患者でも椅子にもたれてぺ ダルを漕ぐリカンベント型エルゴメーターは駆動可能 でありこれらの患者の機能訓練として実施している 施設もある．上肢と比べて下肢の方がより強い負荷で の運動が可能であり ${ }^{2 \sim 4)}$, 我々は片麻痺患者のより快 適な移動手段として, 下肢を駆動力源とする下肢駆動 型車椅子 (Leg-pedaled wheclchair: 以下 LW) が 有効と考えた。これまで, 下肢を駆動力源とする車椅 子の検討は報告があるが5,6), 片麻痺患者を対象とし たものはまれである，そこで今回，片麻痺患者に LW と普通型車椅子 (Ordinary wheelchair：以下 OW) を駆動させ，その特性や問題点を予備的に比較し, 片 麻痺患者における下肢駆動型車椅子の有用性を検討す ることにした。

\section{対象}

初回発作の亜急性期〜慢性期脳卒中片麻瘏患者 5 名 を対象とした。患者の選択基準は，1）発症後 4 週以 上経過，2）下肢ブルンストロームステージ（以下， 下肢ステージ）III または IV，3）研究の趣旨や車椅 子の駆動法を理解できる，4）半側空間無視がない, 5）骨関節疾患の既往がない，6）心拍数に影響する薬 剤や抗精神薬を内服していないこととした。平均年齢 は 60 墄, 脳卒中発症後平均 5.8 力月経過していた。 被験者 5 人の詳細を表 1 に示す.

全員が本研究の目的を理解し, 十分な説明ののち自 主的に参加した。

\section{方法}

下肢駆動型車椅子として EZchair ${ }^{\circledR}$ (Premier design 社製) a を利用した（図 1, 図 2)。この車椅子 は座面の前下方にペダルが設置されており, それを漕 ぐことによりチェーンでつながれた後輪が回転して前 進する.駆動力は左右両側の後輪に伝えられるが，小

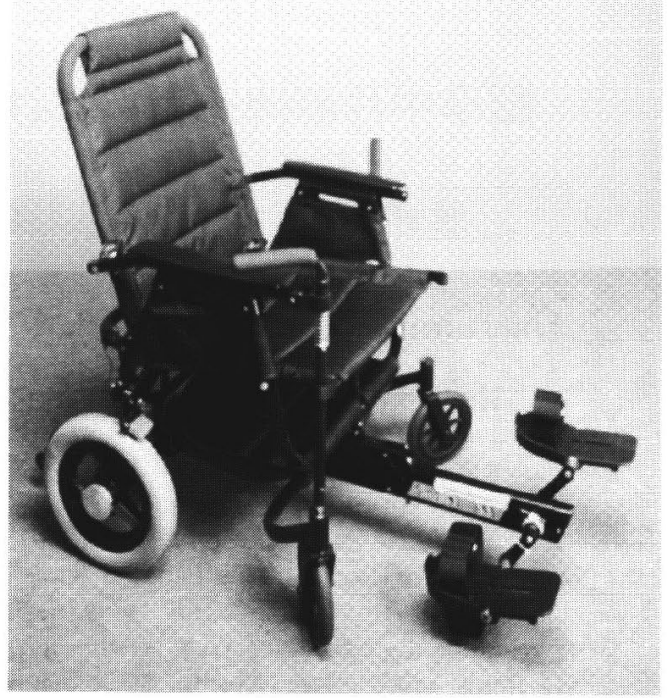

図 1 下肢駆動型車椅子 $\left(\right.$ EZchair $\left.{ }^{\circledR}\right)$ 左片麻痺患者に使用したもので，右側に操舵レバーがあ り, 座面下から前方にシャフトが延び, ペダルが取り付け られている。

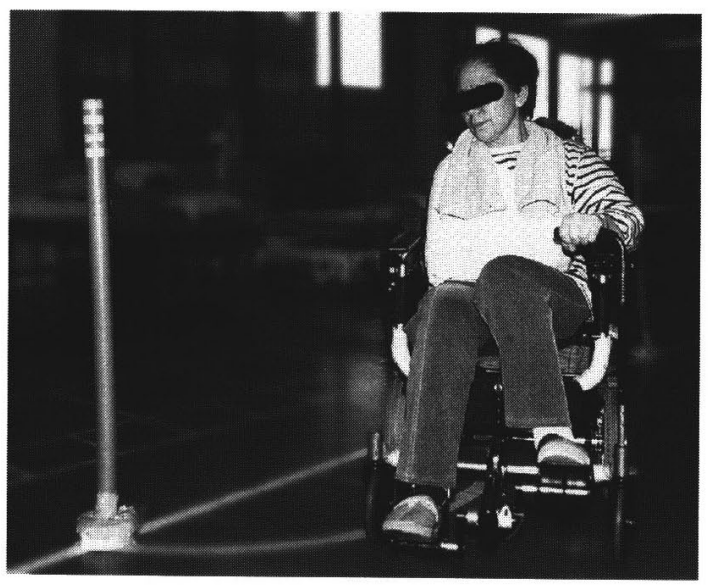

図 2 下肢駆動型車椅子の駆動（右片麻㽻） 右片麻痺患者が両下肢でペダルを漕ぎながら, 健側上肢で キャスターの向きを変えポールを回るところ.

さな回転半径で旋回するために差動装置も備わってい る。片側のキャスターからはバーが值上に伸びてお り，それを非麻痺側上肢で操作することでキャスター の向きを変え, 操舵するようになっている，停止時に 働く固定用のブレ一キはあるが, 減速用のブレーキは 装着されていない，操舵装置が左と右の $\mathrm{EZChair}{ }^{\circledR}$ 各 2 台（大・小）を用意し，各大小の 2 つから被験者の 
体格に合うものを選び，さらに座面の高さ，クランク 長も適宜調整した。麻痺側足部がペダルから脱落する のを防止するため，ベルトも使用した．普通型車椅子 は，当院常備の軽合金フレームで体格に合うものを選 択した。

駆動能力評価として, 駆動速度, 操作性を評価し, また心拍数を測定して Physiological Cost Index（以 下 $\mathrm{PCI})^{7)}$ を算出した.

駆動速度は 1 周約 $40 \mathrm{~m}$ の屋内コース（以下，外周 コース）を 3 分間，可能な限り速い速度で駆動した時 の駆動距離から算出し，その時に心拍数も測定した。

操作性評価は，4 本のポールを $3 \mathrm{~m}$ 間隔で直線上に 並べたコース（以下，スラロームコース）を 3 分間， 可能な限り速い速度でポールに触れないようにスラロ 一ム走行した時の駆動距離と心拍数およびポールへの 接触回数で表した。

駆動距離計測にはCAT EYE 社製 CC-CD $100 \mathrm{~N}$ を 使用, 計測の精度を高めるため回転検知用の磁石を 4 個等間隔（90 度ずつ）に駆動輪に装着した。正確に 計測された $30 \mathrm{~m}$ の直線トラックを 10 回走行し，事 前に距離表示が正確であることを確認した。

心拍数計測には日本電気社製 Bioview 1000 を使 用, 計測用車椅子に乗車後十分な安静をとり, 車椅子 駆動開始時と 3 分間駆動後の心拍数を記録した。これ らの計測值より PCI（拍 $/ \mathrm{m}: 3 \times$ 駆動前後の心拍数変 化/駆動距離）を算出した。

計測は両車椅子で，スラロームコースと外周コース での走行訓練を 7 10 日間行い，駆動や方向転換方法 を習熟した後に行った. 駆動速度評価と操作性評価は 連続する 2 日に分け, 駆動速度と操作性評価の順およ び LW と OW の順は被験者ごとに設定し，車椅子を 替える際は十分な休㮩時間を設けた。

評価値の比較は対応のある $\mathrm{t}$ 検定を用い，有意水準 は 0.05 とした。

\section{結 果}

全員が LW および OW を駆動でき，事故もなく測 定可能であった.

計測結果を図 3, 図 4 に示す．駆動速度は両コース とも LW の方が有意に速く, PCI は外周コースでは LW が有意に低かった。スラロームコースでのポール への接触は，OWで 1 例に 1 回見られたのみで，方 向転換時に駆動が滞ることもなかった。

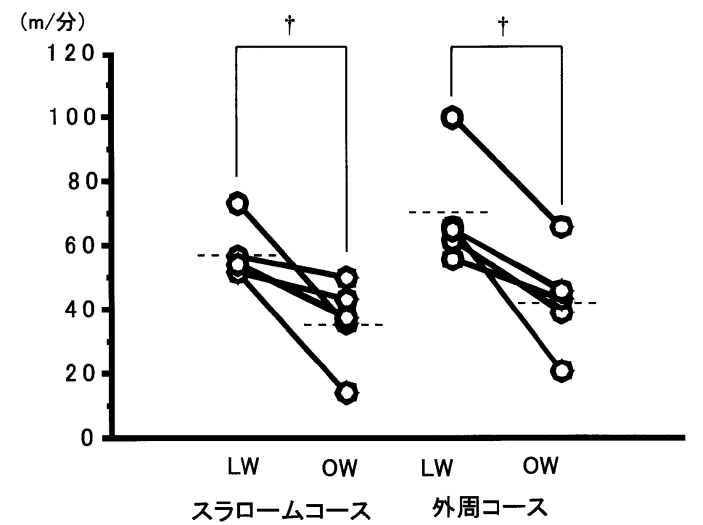

図 3 各コースにおける駆動速度 LW：下肢駆動型車椅子, $\mathrm{OW}$ : 普通型車椅子, PCI： Physiological Cost Index. -...: 平均, †: 対応のある $\mathrm{t}$ 検定, $p<0.05$

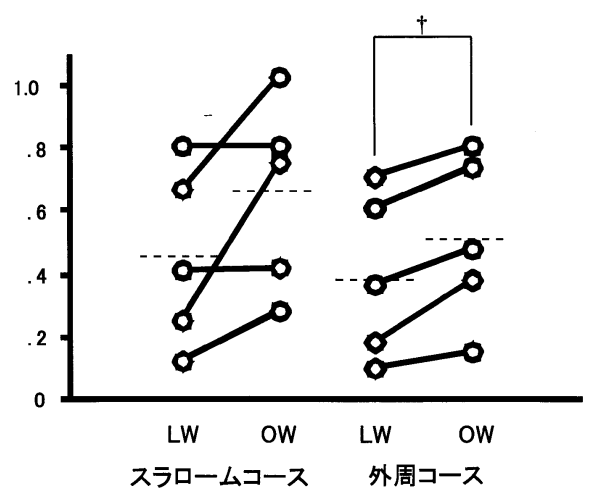

図4 各コースにおける PCI

$\mathrm{LW}$ ：下肢駆動型車椅子, $\mathrm{OW}$ ：普通型車椅子, PCI： Physiological Cost Index. - - : 平均, †: 対応のある $\mathrm{t}$ 検定, $p<0.05$.

また，今回使用した LW は座面の前下方にシャフ トとペダルがあり移乗の障害となっており，OWで は介助なしに移乗できたが，LW では体を回転する際 のバランス支持や患肢をシャフトの反対側に跨ぐ際 に，被験者全員が何らかの介助を要した。

\section{考察}

片麻痺患者が車椅子を駆動する場合，非麻痺側の上 下肢を用いることが一般的である。この場合，特に下 肢で駆動し操舵も担うため，座面は下肢が床に届くよ う低く設定し，非麻痺側のフットレストや患側のハン ドリムは取り除かれることが多い. Lee ら ${ }^{1)}$ は非麻痺 
側上下肢で車椅子を駆動する片麻痺患者と両上肢で駆 動する健常者を比較すると, 片麻痺患者の方が駆動速 度は遅く，斜面での片寄りが多かったと報告した。今 回我々は，同一患者に異なる駆動方式の車椅子を操作 させて比較検討したが，LW の方が駆動速度は速く, PCI は低く，下肢ペダリング動作による車椅子駆動の 方の効率が良いことが判明した．スラロームコースで は異なる車椅子間で PCI に有意差がなかったことは, 外周コースに比べ速度が低く心拍数に影響するほどの 負荷とはならなかったためであろう。

片麻痺患者は日常生活の中で積極的に運動すること が少なく，運動習慣に乏しい傾向にある．そのため神 原ら ${ }^{8)}$ の報告にもあるように，片麻痺患者において PCI の計測を行う場合, 日常の活動量を考慮する必要 があり, 今回の結果を対麻痺や四肢麻痺患者の車椅子 駆動時の PCI を用いた研究とは比較できない.

スラロームコースにおいてポールに接触したのは OW で 1 例, 1 回のみであり, スラロームコースで も，LW と OW のコントロール性に関して大きな差 は見られなかった。

一方，（1）減速装置が備わらない，（2）移乗が困 難といつた $\mathrm{LW}$ の問題点もいくつか指摘された。こ のように LW には改善すべき問題点があるが，その 駆動効率の良さは被験者全員も認めており，片麻痺患 者の屋外の移動手段としておおいに期待できる．近 年，屋外の移動手段としてユニット型をはじめとする 電動車椅子を利用する片麻痺患者も見られる。これら の操作は容易で取り迴しも良く便利であるが, 運動機 能障害者におけるフィジカルフィットネスの重要性は 報告されていることであり9), 効率の良い LW では移 動距離が OWよりも伸びることが予想され，実用性 とフィットネス効果の両立ができると考える. また, Christensen ら ${ }^{10)}$ は，自転車漕ぎのようなリズミカル な運動により1次運動野, 補足運動野および小脳が活 性化されると報告しており，移動手段やフィットネス としてばかりではなく脳の活性化も期待できるかもし れない.

今回の検討は下肢ステージが III または IV の患者 を対象とし, 駆動方法も限られた状況のみでの予備的 研究であるが，片麻痺患者における車椅子下肢駆動の 有用性が示された，今後は様々な状況や駆動方法にお
ける特性および問題点を調査し，片麻痺患者が使用し やすい LW を開発する必要がある。

\section{結語}

脳卒中片麻痺患者は下肢駆動型車椅子の駆動が可能 であり, 普通型車椅子よりも駆動速度は速く，PCI も 低く，その駆動効率は良好であった。下肢駆動は移乗 や減速に問題はあるが，改良を加えることにより今後 片麻瘏患者の移動手段として期待できる。今後より多 くの場面を想定した研究を行う必要がある。

サプライヤ

a ファンライフ：神奈川県横浜市中区住吉町 1-12-1 日 本興亜関内ビル 4 階

\section{文献}

1) Kirby RL, Ethans KD, Duggan RE, Saunders-Green LA, Lugar JA, Harrison ER: Wheelchair propulsion: descriptive comparison of hemiplegic and two-hand pattern during selected activities. Am J Phys Med Rehabil 1999 ; 78 : 131-135

2) Louhevaara V, Sovijarvi A, Ilmarinen J, Teraslinna $\mathrm{P}$ : Differences in cardiorespiratory responses during and after arm crank and cycle exercise. Acta Physiol Scand $1990 ; 138$ : 133-143

3) Ahlborg G, Jensen-Urstad M : Metabolism in exercising arm vs. leg muscle. Clin Physiol 1991; 11: 459-468

4) Aminoff T, Smolander J, Korhonen O, Louhevaara V: Prediction of acceptable physical work loads based on responses to prolonged arm and leg exercise. Ergonomics $1998 ; 41: 109-120$

5) Stein RB, Roetenberg D, Chong SL, James KB : A wheelchair modified for leg propulsion using voluntary activity or electrical stimulation. Med Eng Phys 2003; 25 : 11-19

6) Stein RB, Chong SL, James KB, Bell GJ : Improved efficiency with a wheelchair propelled by the legs using voluntary activity or electric stimulation. Arch Phys Med Rehabil 2001; 82 : 1198-1203

7) Kenedi RM, Paul JP, Hughes J (eds) : Disability. MacMillian, London, 1979

8）神原孝子：片麻痺患者の歩行能力評価 PCI を用いて. 理学療法科学 $1997 ; 12$ : 183-186

9）二瓶隆一: 運動機能障害者のフィットネスとスポー ツ.臨床スポーツ医学 $1995 ; 11: 1221-1225$

10) Christensen LOD, Johannsen $P$, Sinkjær T, Petersen $\mathrm{N}$, Pyndt HS, Nielsen JB: Cerebral activation durng bicycle movement in man. Exp Brain Res $2000 ; 135: 66-72$ 